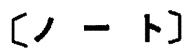

\title{
第三アミン存在下における $\alpha, \alpha^{\prime}$-ジハロ-p-キシレンと ビスフェノールA との相間移動重樎合*
}

\author{
山崎 昇*1 $・$ 今井淑夫*1
}

(受付 1985 年 9 月 25 日・藉查終了 1985 年 10 月 22 日)

\begin{abstract}
要 旨 $\alpha, \alpha^{\prime}$-ジクロロ-p-キシレン(DCPX) とビスフェノールAとの重縮合反応に扰いて，第三丁 ミンを添加し，DCPX からテトラヒドロフラン (THF)一ジチルスルホキシド (DMSO) (3:1) 混合 媒中で第四厂ンモニウム埴を生成させ，この㙋を単離することなしに $50 \% \mathrm{NaOH}$ 水溶液を作用 させると粘度 $0.32 \mathrm{~d} / / \mathrm{g}\left(30^{\circ} \mathrm{C}, \mathrm{NMP}\right.$ 中) のポリエーテルが生成した。 DCPX と第三アミンとから 生成した第四ナンモニウム醏は，生成ボリエーテルの末端に取りこまれてしま5ため，重編合反応の 初期沈おいてはベンジルトリエチルナンモニウムクロリドと同程度の蚛某活性を示すが，重合時間及 び生成ボリエーテルの粘度の增大に伴って失活した。
\end{abstract}

\section{1 藉}

・シレンジクロリド (DCPX) とビスフェノール A (BPA) とから相間移動触媒（第四アンモニウム塩）の 存在下でボリェーテルを合成するための諸条件について 検討を行ってきたが(1),2)，本研究は第四フンモニウム 塩を DCPX とトリアルキルアミンとから反応乎中で生 成させ，これを単離せずに相間移動触媒 (PTC) として 利用し，ポリーーテル合成を行おらとしたるのである. 相間移動重縮合によるポリエーテル合成には, Fig. 1 K 示したよう，DCPX とBPA に対して第四フンモニウ 厶塩 $\left(\mathrm{R}_{4} \mathrm{~N}^{+} \mathrm{Cl}^{-}\right)$を相間移動触媒として加え，50\% $\mathrm{NaOH}$ 水容液を用いて反応させる 徒来法 (A法) と, 本研究のB法とか洘えられる. B法においては，DCPX と BPA K $\mathbf{R}_{3} \mathbf{N}$ を加え，しばらくメンシュトキン反応 (四級化反応) を行わせて $\mathrm{Q}^{+} \mathrm{Cl}^{-}$の様な第四フンモニウ 厶塩を生成させ，次いで $50 \% \mathrm{NaOH}$ 水溶液を加えて 重合を行いポリェーテルを得ようとするすのである。こ こではA法とB法の比較す併せて行った.

\section{2 实酸}

\section{1 試葙}

キシレンジクロリド (DCPX), ビスフェノール $\mathbf{A}$ (BPA) は，それぞれ再結晶して用いた。トリェチルフ ミン (TEA), トリブロビルフミン (TPA), トリブチル

゙本報を「相閣移䖝䖵媒を用いるボリエーテルの合成 第 4 啹」とする。

*1 東京工莱大学工学部有機材料工学科（西152 東京都 目黑区大岡山 2-12-1)
フミン (TBA), トリアミルフミン (TAA), トリヘキシ ルアミン (THA), 及びトリオクチルフミン (TOA) 及 びヘンンジルトリエチルアンモニウムクロリト (BTEAC) は，市販品をそのまま使用した。

\section{2 臬合方法}

A法：前報1)2)に準じて行った.

B法: DCPX $(5.5 \mathrm{mmol})$, BPA $(5.0 \mathrm{mmol}), ト$ リ フルキルアミン (1.0 mmol) を THF: DMSO (3:1) の混合溶媒 $20 \mathrm{ml}$ に溶解し, $60^{\circ} \mathrm{C}$ で所定時間メンシニ トキン反応を行 5. 次いで $50 \% \mathrm{NaOH}$ 水溶液 $20 \mathrm{ml}$ を一度に加え，1時間激しくかきませる. 反応液を氷水 中に投入し，希塩酸で中和した後，ポリマーをろ別し， 水洗及びィタノール洗浄をよく行い，減任㛺燥する．粘 度は，N-メチル-2-ピロリドン (NMP) を溶媒とし， 0.5 $\mathrm{g} / \mathrm{d} l$ の䈨度, $30^{\circ} \mathrm{C}$ で測定した.

\section{3 結果及び考察}

$\mathrm{DCPX}$ にトリアルキルアミン $\left(\mathbf{R}_{8} \mathrm{~N}\right)$ を反応させた場 合, 式 (1)のよ5に反応し, 生成した第四アンモニウム 塩 $\left(\mathrm{Q}^{+} \mathrm{Cl}^{-}\right)$は, アルカリ水洛液と接触したとき相間移 動触媒として作用し，式 (2) 従ってポリエーテルが生 成すると考えられる。

DCPX $(5.5 \mathrm{mmol})$, BPA $(5.0 \mathrm{mmol})$, TEA $(1.0$ mmol) を THF:DMSO (3:1) 混合溶媒中, $60^{\circ} \mathrm{C}$ でメ ンシュトキン反応を行い，次いで $50 \% \mathrm{NaOH}$ 水溶液 の作用で重合反応を行った時の,メンシュトキン反応時 間と生成ポリマーの粘度との成係を Fig. 2 に示した. メンシュトキン反応を 30 分以上行らと，粘度約 0.25 $\mathrm{d} l / g$ のポリエーテルが得られ, TEA 共存下では粘度 


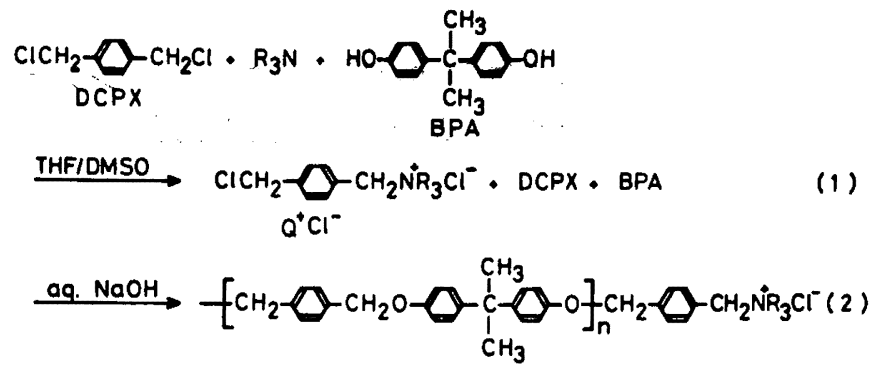

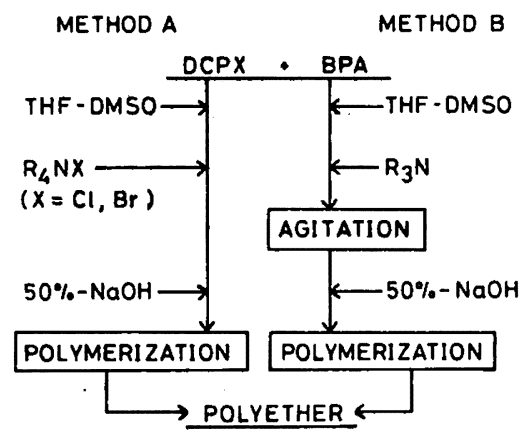

Fig. 1. Flow chart for the polymerization methods.

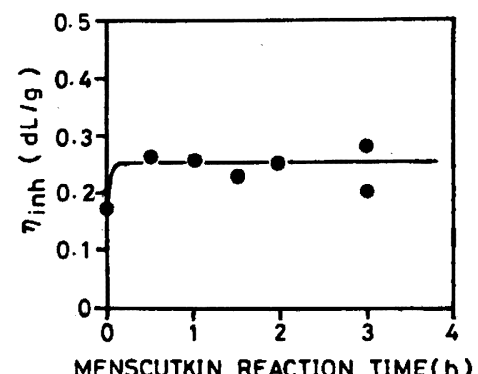

Fig. 2. Time-dependence curve of inherent viscosity of the resulting polymer on the Menschutkin reaction of TEA with DCPX in THF-DMSO $(3: 1)$ at $60^{\circ} \mathrm{C}$.

$0.18 \mathrm{~d} / \mathrm{g}$ ，TEA あるいはその他の相間移動触媒の存在 しない場合は粘度 $0.12 \mathrm{~d} l / g$ のポリマーが生成した。こ のことから，式 (1) と（2）に示したように生成した $\mathrm{Q}^{+}$ $\mathrm{Cl}^{-}$が触媒作用を示していると考えられる.

TEA の使用量を $1.0 \mathrm{mmol}$, BPA $5.0 \mathrm{mmol}$ と 一定とし，DCPX の量を変化させたメンシュトキン反 応を 3 時間行った後, 1 時間重合すると, Fig. 3 下示 したように [DCPX]/[BPA] =1.15 で生成ポリマーの粘 度が極大となることがわかった，更に BPAを 5.0 $\mathrm{mmol}$ と一定としておき，TEAを2([DCPX]-[BPA])

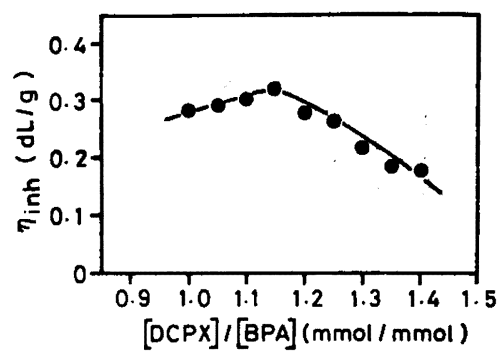

Fig. 3. Changes of inherent viscosity of the resulting polymer by molar ratio of DCPX to BPA. After $3 \mathrm{~h}$ of Menschutkin reaction of TEA with DCPX, polycondensations were carried out in THF-DMSO (3:1)/50\% aqueous $\mathrm{NaOH}$ system at $60^{\circ} \mathrm{C}$ for $1 \mathrm{~h}$.

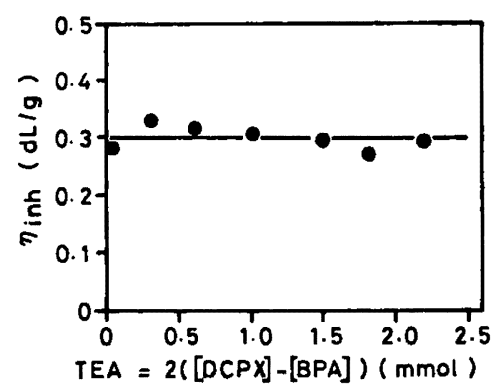

Fig. 4. Changes of inherent viscosity of the resulting polymer by a concentration of TEA. Menschutkin reaction between DCPX (5.0-6.1 mmol) and TEA (2[DCPX]-[BPA] mmol]) was carried out for $3 \mathrm{~h}$ with $5.0 \mathrm{mmol}$ of BPA, followed by polycondensation at $60^{\circ} \mathrm{C}$ for $1 \mathrm{~h}$ in the presence of $50 \%$ aqueous $\mathrm{NaOH}$.

$\mathrm{mmol}$ 使用し， 3 時間メンシュトキン反応後，50\% $\mathrm{NaOH}$ 水溶夜を作用させ 1 時間重合反応した訝合には， Fig. 4 に示したよらに生成ボリマーの粘度は約 $0.3 \mathrm{~d} / / \mathrm{g}$ で一定であった．これらのことは，DCPX の一部が TEA と反応し第四アンモニウム塩を生成方ため，棌 加した TEA の量に見合う分たけ DCPX を過剩使用 
第三フミン存在下における $\alpha, \alpha^{\prime}$-ジハロ-p-キシレンとビスフェノールAとの相閃移轩重狳合

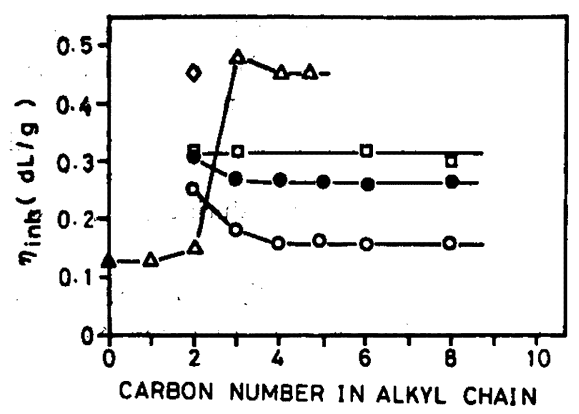

Fig. 5. Changes of inherent viscosity of the resulting polymer by the carbon number in alkyl chain of the catalyst or trialkylamine.

Polycondensations were carried out in a THFDMSO (3:1)/50\% aqueous $\mathrm{NaOH}$ system at $60^{\circ} \mathrm{C}$ for $1 \mathrm{~h}$ with BTEAC $(\diamond), \mathbf{R}_{\mathbf{A}} \mathbf{N}^{+} \mathbf{B r}^{-}(\Delta)$, or after $2 \mathrm{~h}(0), 3 \mathrm{~h}(O)$, or $5 \mathrm{~h}(\square)$ of Menschutkin reaction of $\mathrm{R}_{8} \mathrm{~N}$ with $\mathrm{DCPX}$.

すればよいことを示している.

各種トリアルキルアミンを使用して,メンシュトキン 反応を 2，3，5 時間行った後，フルカリの作用下で 1 時間重合反応して得られた生成ボリマーの粘度と使用し たトリフルキルアミンの炭素数との閔係を Fig. 5 に示 した， 2 時間のメンシュトキン反応では，トリフルキル フミンの炭轰数が增大するに従って生成ポリマーの粘度 は減少し, TBA 以上では生成ボリマーの粘度は約 0.15 $\mathrm{d} l / \mathrm{g}$ と一定になった. 3 時間のメンシュトキン反応で は，TPA 以上で約 $0.28 \mathrm{~d} l / g$ のポリマーが生成した. 5 時間のメンシュトキン反応では，使用したトリフルキ ルアミンの炭素数 (フルキル基の鎖長) には関俰なく, $0.32 \mathrm{~d} l / \mathrm{g}$ の粘度のポリマーが生成した. これは, トリ アルキルアミンと DCPX とのメンシュトキン反応には 長鎖のむの洼ど長時間が必要であり，3ないし 5 時間で 平衡に達することを示している.

また Fig. 5 Кは，A法により各䑶テトラフルキルフ ンモニウムブロミト ( $\left.\mathbf{R}_{\mathbf{4}} \mathbf{N}^{+} \mathbf{B r}^{-}\right)$を相間移動触媒として 重合したときの結果も並記した。フルキル基の鎖長が 3 以上になると第四フンモニウム塩の方がより高重合度の ボリエーテルが生成することがわかる。これは Fig. 6

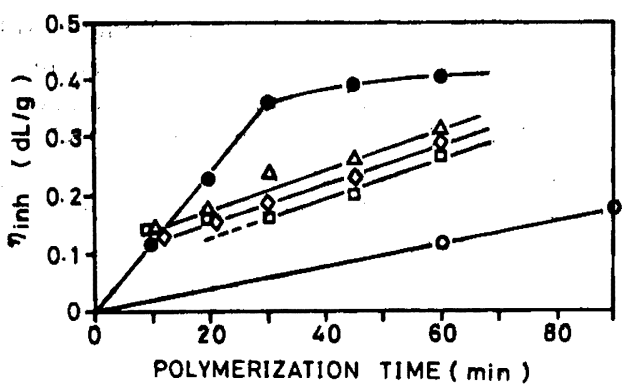

Fig. 6. Time-dependence curve of inherent viscosity of the resulting polymer.

In the presence of BTEAC ( $\bullet)$, in the absence of catalyst $(O)$, or after $3 \mathrm{~h}$ of Menschutkin reaction of TEA $(\Delta)$, TPA $(\diamond)$, or TOA $(\square)$ with DCPX, polycondensations were carried out in THF-DMSO (3:1)/50\% aqueous $\mathrm{NaOH}$ system at $60^{\circ} \mathrm{C}$.

の結果からもかかるよらに，B法のよらな重合系では生 成したアンモニウム塩が成長分子末端に取り込まれるた め，触媒として充分に機能しなくなると考えられる。

Fig. 6 には，TEA，TPA，TOAを用いて 3 時間メ ンシュトキン反応を行った後，相間移動重合を行い，重 合時間と生成ポリマーの粘度との関係を示した. 重合反 応初期の 10 分以内は, BTEAC と同様の結果を示す が，20 60 分の間では BTEAC 存在下よりむしろ触媒 なしで重合した場合の粘度上昇速度に近いことがわか る.このことは, 重合初期において，メンシュトキン反 応で生成した第四アンモニウム塩が生成ボリマーの末端 に取りこまれてしまうため，相間移動触媒としての効果 が減少してしまらものと考えられる。

付粑本研究住第 33 回高分子时論会（1984 年 9 月 仙台）で発表した。

\section{文献}

1) N. Yamazaki and Y. Imai, Polym. J., 15 (8), 603 (1983); $17(2), 377$ (1985).

2) 山崎 并, 今井淑夫, 高分子踚文集, $42(1)$, 49 (1985).

\section{[Notes]}

Phase Transfer Catalyzed Polycondensation of $\alpha, \alpha^{\prime}$-Dichloro-p-xylene with 2,2-Bis(4-hydroxyphenyl)propane in the Presence of Trialkylamine*

Noboru YAMAZAKI* and Yoshio IMA1*1

* Studies on the Phase Transfer Catalyzed Polycondensation. IV.

*1 Department of Textile and Polymeric Materials, Faculty of Engineering, Tokyo Institute of Technology (Ookayama, Meguro-ku, Tokyo, 152 Japan)

First, a quaternary ammonium salt was produced by Menschutkin reaction between $\alpha, \alpha^{\prime}$-dichloro-p- 
xylene (DCPX) and trialkylamine. Without isolating this quaternary ammonium salt, polycondensation between DCPX and 2,2-bis-(4-hydroxyphenyl)propane was carried out in tetrahydrofuran (THF)-dimethyl sulfoxide (DMSO) $(3: 1)$ solution by the addition of $50 \%$ aqueous sodium hydroxide to produce a polyether $\left(\eta_{1 \mathrm{nh}}=0.32 \mathrm{~d} / \mathrm{g}\right.$ in $N$-methyl-2-pyrrolidone $(\mathrm{NMP})$ at $\left.30^{\circ} \mathrm{C}\right)$. The quaternary ammonium salt, existing at the end of growing polymer chain, showed nearly the same catalytic activity as benzyltriethylammonium chloride at the initial stage of the polymerization. The activity decreased gradually during the course of polycondensation.

KEY WORDS Phase-Transfer Catalyzed Polycondensation / Polycondensation / Polyether / Quaternary Ammonium Salt / $\alpha, \alpha^{\prime}$-Dichloro-p-xylene / 2,2-Bis(4-hydroxyphenyl)propane / Menschutkin Reaction / Trialkylamine /

(Received September 25, 1985: Accepted October 22, 1985)

[Kobunshi Ronbunshu, 43 (2), 105-108 (1986)] 